\title{
Michal Meidan (ed.), Shaping China's Energy Security: The Inside Perspective
}

Thierry Kellner

\section{CpenEdition}

\section{Journals}

Édition électronique

URL : http://journals.openedition.org/chinaperspectives/5363

DOI : 10.4000/chinaperspectives.5363

ISSN : 1996-4617

Éditeur

Centre d'étude français sur la Chine contemporaine

Édition imprimée

Date de publication : 15 décembre 2010

ISSN : 2070-3449

Référence électronique

Thierry Kellner, "MICHAL MEIDAN (ED.), SHAPINg CHINA'S ENERgY SECURITY: THE INSIDE PERSPECTIVE 》,

China Perspectives [En ligne], 2010/4 | 2010, mis en ligne le 11 février 2011, consulté le 24 septembre 2020. URL : http://journals.openedition.org/chinaperspectives/5363 ; DOI : https://doi.org/10.4000/ chinaperspectives.5363

Ce document a été généré automatiquement le 24 septembre 2020

(c) All rights reserved 


\title{
Michal Meidan (ed.), Shaping China's Energy Security: The Inside Perspective
}

\author{
Thierry Kellner
}

1 Michal Meidan (ed.), Shaping China's Energy Security: The Inside Perspective, Paris, Asia Centre/Centre études Asie, 2007, 239 pp.

Claude Mandil, former Executive Director of the International Energy Agency, said last year that the global system is facing a triple crisis: supply crisis, climate crisis, and economic crisis. ${ }^{1}$ Those who are part of this system will have to ensure increased energy output even as they are forced to make significant cuts in greenhouse gases in order to deal with climate change. Mankind thus faces an unprecedented challenge. A crucial part of the effort in resolving this new energy equation will have to be implemented in Asia, especially in China. The average Chinese now consumes less than one TOE/year, ${ }^{2}$ against four TOE/year used by a European and eight TOE/year by an American. This situation is bound to change. After more than two decades of rapid economic growth, a rising number of Chinese wish to enjoy the same levels of consumption as in industrialised countries. In the automotive sector alone, should China reach European levels, it would have a fleet of 700 million cars and the entire oil output from the Middle East would be needed to keep them running! Such examples of astounding potential demand can be extended to other sectors. In this context, Beijing's energy choices will have a major bearing not only on China itself but on the planet as a whole. A knowledge of China's energy sector, the reforms it has undergone since the 1990s, reasons behind and hurdles facing these reforms, its current organisation, key actors, the difficulties and myriad obstacles confronting it, the policies pursued and achievements made, the advances of recent years, and finally, future priorities and constraints, all make for major fields of study.

This book edited by Michal Meidan, stemming from a 2006-2007 research project including five roundtables that brought together Western and Chinese academics and industry insiders, is a timely effort to clarify some of these issues with the help of a wealth of data. The chapters of the book, which has an extensive introduction by François Godement and Meidan, are in four parts. The first deals with 
"institutional challenge," one of the often ignored major problems China faces in energy security matters. In the first chapter, Meidan, Philips Andrews-Speed, and Ma Xin lay out an analytical framework for China's energy policy (structure, players, influences, determining factors, and constraints). The second by Erica Downs recounts the evolution of institutions dealing with energy issues in China and the institutional obstacles in the way of ensuring energy security. The book's second part explores sector-wise dimensions of energy security. Brian Ricketts offers a global perspective of the coal sector - China's most important source of primary energy (chap. 3). In the following chapter, Shi Dan considers structural reforms in China's oil industry, achievements, and problems. In Chapter 5, Wei Bin examines reforms in the power industry. The third part turns to policy tools and incentive systems. In Chapter 6, Yang Lan, Mao Xianqiang, Liu Zhaoyang, and Xing Youkai explore the question of adopting an energy tax as well as its positive, and negative, effects on China's economy and society. Wang Mingyuan in Chapter 7 offers a legal analysis of the supervision system for implementing the clean development mechanism (CDM) under the Kyoto Protocol, of which China is a major beneficiary. Finally, Part Four deals with China's energy security issues in a global perspective. Yu Hongyuan in Chapter 8 dwells on China's diplomacy in handling the delicate issue of climate change. He provides a clear background to help understand Beijing's positions during the Copenhagen conference (December 2009). Chapter 9 by Tadakatsu Sano recounts Japan's experience in energy policy since the end of the Second World War and points to courses of action China could learn from. The book ends with Meidan's useful synthesis of the major points raised.

This important book not only brings an original perspective to China's energy security issues but does so relying largely on analysis by Chinese sector players themselves and their perceptions of the energy challenges facing the nation. It contains valuable factual information - for instance on the nature of relations between national oil firms and the government - and erudite analysis space does not permit recounting. More generally the book helps correct some clichés rooted in Western literature. To take just one, the reader finds that the perception of "energy insecurity" has evolved considerably in China, and that since 2006, many Chinese experts have come to see that "oil security" - which has been a preoccupation in the West and elsewhere - is not, in fact, a problem for Beijing. The book usefully points out that a major part of China's energy insecurity is owing to internal factors (institutional weakness, environmental insecurity, price-setting ignoring market forces ...) and not due to the international situation. This book should be essential reading for researchers, students, and journalists, but also decision-makers who want to be well informed of the challenges and constraints facing China as well as of the initiatives and some highly impressive responses that the Beijing authorities have come up with. It is to be hoped that the book will be updated and reissued to take note of the substantial changes since 2007. It would be useful also to explore other sector analysis (of the gas sector but also renewable energy and nuclear power, for example), changes in China's positions on climate change, relations with the International Energy Agency, or the proliferation of bilateral and multilateral cooperation in the energy field. 


\section{NOTES}

\section{Translated by N. Jayaram}

1. Claude Mandil, "Foreword," in Jean-Marie Chevalier (ed.)The New Energy Crisis: Climate, Economics and Geopolitics, Palgrave Macmillan, 2009, p. xiv.

2. Tonnes of oil equivalent. 